\title{
Antibodies to RNA Polymerase II (B) Inhibit Transcription in Lampbrush Chromosomes after Microinjection into Living Amphibian Oocytes
}

\author{
Marion Bona, Ulrich Scheer ${ }^{1}$ and Ekkehard K. F. Bautz \\ Molecular Genetics, University of Heidelberg \\ D-6900 Heidelberg, Federal Republic of Germany and \\ ${ }^{1}$ Division of Membrane Biology and Biochemistry \\ Institute of Cell and Tumor Biology \\ German Cancer Research Centre \\ D-6900 Heidelberg, Federal Republic of Germany
}

(Received 16 April 1981, and in revised form 4 May 1981)

\begin{abstract}
Antibodies directed against RNA polymerase II (B) from Drosophila melanogaster were obtained from rabbit sera and, as monoclonal immunoglobulins, from mouse hybridomas and shown to cross-react with the amphibian enzyme protein. Localization by indirect immunofluorescence microscopy revealed the association of this enzyme with chromatin of interphase nuclei of amphibian cells and its absence in nucleoli. Purified immunoglobulins were microinjected into nuclei of living vitellogenic oocytes of Pleurodeles waltlii and Xenopus laevis and their effects on transcriptional processes were monitored by biochemical and light and electron microscopic studies. RNA polymerase II antibodies from rabbit sera caused a rapid and almost complete release of nascent transcripts from the chromatin axis of the loops of lampbrush chromosomes, followed by collapse of the loops and their retraction on the main chromosome axis. Monoclonal murine antibodies to the large RNA polymerase II subunits also inhibited transeription in chromosome loops but appeared to inhibit initiation rather than elongation events. Activities of class I and III RNA polymerases were not significantly affected by injection of antibodies to polymerase II, indicating immunological differences between the three RNA polymerases. The potential value of the in vitro test system described, as a very sensitive assay for detecting proteins involved in transcription in living cells, is discussed.
\end{abstract}

\section{Introduction}

Antibodies raised in rabbits against purified RNA polymerase II (B) from Drosophila melanogaster (Greenleaf \& Bautz, 1975) and monoclonal antibodies to defined RNA polymerase II subunits of the same insect (Krämer et al., 1980) have been successfully used to study the distribution of this enzyme on polytene 
chromosomes and in cultured cells by immunofluorescence microscopy (Plagens et al., 1976; Jamrich et al., 1977,1978; Krämer et al., 1980). While this experimental approach exploits the specific binding of the antibodies to the antigen for detecting and localizing the enzyme in situ, we became interested in the question of whether the binding of the antibody would also interfere with transeriptional events in the living cell. It has been shown by several authors that the enzymatic activities of eukaryotic RNA polymerases can be inhibited by incubation with specific antibodies when assayed in vitro, both in homologous and heterologous combination (Ingles, 1973; Hildebrandt et al., 1973; Kedinger et al., 1974; Somers et al., 1975; Hossenlopp et al., 1975; Lobban et al., 1976; Buhler et al., 1976,1980; Greenleaf et al., 1976; Krämer \& Bautz, 1981). However, some antibodies shown to bind RNA polymerases failed to inhibit enzymatic activity in vitro (Krämer \& Bautz, 1981), a test that usually measures the cataly tic function of RNA polymerase but not correct initiation at promoter sites or (hypothetical) interactions with transcription factors. Thus, in order to study the complex transcriptional process in vivo we have sought to interfere with the transcription process by injecting antibodies to RNA polymerase II into living amphibian oocytes according to the procedure described for histone antibodies (Scheer et al., 1979a). Lampbrush chromosomes of amphibian oocytes offer the unique advantage that their structural organization is directly correlated with their specific transcriptional activity. Inhibition of transcription by drugs like actinomycin $\mathrm{D}$ or $\alpha$-amanitin results in structural changes of the morphology of the lateral loops, followed by retraction of the loops onto the chromosome axis, a process that is readily visualized in the light microscope (Izawa et al., 1963; Mancino et al., 1971; Snow \& Callan, 1969) and can be analyzed in greater detail by electron microscopic techniques (Scheer, 1978; Scheer et al., 1979a). Furthermore, transcription of the genes catalyzed by class I and III RNA polymerases and their transcriptional products can also be readily analyzed in the same cell by electron microscopic and/or biochemical techniques (for references see Sommerville, 1977), especially after injection of high amounts of cloned genes into the nucleus (e.g. see Brown \& Gurdon, 1977; Kressmann et al., 1978).

The availability of monoclonal antibodies directed against defined subunits of RNA polymerase II (Krämer et al., 1980) ensures that perturbing effects on enzyme activities and related physiological processes are in fact due to their direct binding to constitutive subunits of the polymerase molecule and not, for instance, to other associated components (see also Kedinger et al., 1974). The observations described in the present study demonstrate that: (1) injection of antibodies against RNA polymerase II into the nucleus of living amphibian oocytes selectively blocks transcriptional events involving RNA polymerase II ; and (2) this inhibition results in the immediate condensation of the previously transcribed chromatin.

\section{Materials and Methods}

(a) Antibodies

Antibodies against RNA polymerase II isolated from D. melanogaster larvae were elicited from rabbits essentially as described by Greenleaf \& Bautz (1975). The production and 
characterization of monoclonal antibodies directed against the 2 large subunits of the RNA polymerase II have been described by Krämer et al. (1980). Antibodies were obtained from the ascites fluids of Balb/c mice injected with the clone 3 hybridoma cells (Krämer et al., 1980). Non-immune control sera were obtained from several untreated rabbits and mice. The immunoglobulin G (IgG) fractions were obtained and purified by column chromatography on DEAE-cellulose (DE52, Whatman Ltd, Maidstone, England) as outlined by Bustin et al. (1977) and finally dialyzed against TBS $(0 \cdot 1 \mathrm{~m}-\mathrm{NaCl}, 10 \mathrm{~mm}-\mathrm{Tris} \cdot \mathrm{HCl}, \mathrm{pH} 7 \cdot 4)$ or PBS $(0 \cdot 14 \mathrm{~m}-\mathrm{NaCl}, 2 \mathrm{~mm}-\mathrm{KCl}, 10 \mathrm{~mm}-\mathrm{Na} / \mathrm{K}$-phosphate buffer, $\mathrm{pH} 7 \cdot 4)$.

\section{(b) Indirect immunofluorescence microscopy}

Kidney epithelial cells of Xenopus laevis (line A 6 ; Rafferty, 1969) were grown on glass coverslips, washed briefly with PBS, fixed for 5 min with methanol at $-20^{\circ} \mathrm{C}$, dipped 5 times in acetone at $-20^{\circ} \mathrm{C}$ and then air-dried. Small pieces of liver from Pleurodeles waltlii were frozen in isopentane kept in liquid nitrogen. Cryosections were air-dried overnight, then fixed with $2 \%$ formaldehyde (prepared from paraformaldehyde) in PBS for 10 min at room temperature and washed thoroughly by several changes of PBS. The cells and the sections were then incubated for $30 \mathrm{~min}$ at room temperature with the different IgG solutions (20 to $100 \mu \mathrm{g} / \mathrm{ml}$ ), washed 5 times in PBS and then incubated with fluorescein isothiocyanate (FITC)-conjugated goat anti-rabbit IgG diluted $1: 10$ or, when using monoclonal antibodies, FITC-conjugated rabbit anti-mouse IgG (Miles-Yeda, Rehovot, Israel). After $30 \mathrm{~min}$ incubation at room temperature, the preparations were again washed with PBS and finally mounted in Moviol 4-88 (Hoechst AG Frankfurt, F.R.G.). Photographs were taken with a Zeiss photomicroseope (Carl Zeiss, Oberkochen, F.R.G.) equipped with epifluorescence illumination using oil-immersion planapo-objectives $(\times 40$ and $\times 63)$.

\section{(c) Microinjection}

X. laevis females were obtained from the South African Snake Farm (P.O. Box 6, Fish Hoek, Cape Province, South Africa) and P. waltlii from the Station d'acclimation et d'élevage (Bouillé-St Paul, France). Pieces of ovary were removed from anaesthetized animals and placed in modified Barth's medium (Gurdon, 1976). Vitellogenic oocytes of Pleurodeles (approx. $1 \mathrm{~mm}$ in diameter) were mechanically freed from the surrounding follicle epithelium and then centrifuged as described (Scheer et al., 1979a) in order to translocate the nucleus to the animal pole, thereby facilitating nuclear injection. Individual full-grown oocytes of Xenopus were injected, aiming at the nucleus as described by Gurdon (1976). In all experiments the injected volume was 10 to $15 \mathrm{nl}$ per nucleus; for each experiment 10 to 50 oocytes were injected.

\section{(d) Light and electron microscopy of lampbrush chromosomes and amplified nucleoli}

Preparations were made as described by Scheer et al. $(1976,1979 a)$. Electron micrographs were taken with a Zeiss EM 10 A (Carl Zeiss, Oberkochen, FRG).

(e) Gel electrophoresis of RNA labeled in the presence and absence of antibodies to RNA polymerase II

A recombinant plasmid containing a lysine and an isoleucine transfer RNA gene from Drosophila inserted into pBR 322 was kindly provided by B. Hovemann (Institute of Molecular Genetics, University of Heidelberg; see also Hovemann et al., 1980). This plasmid was injected into nuclei of Xenopus oocytes along with tritiated UTP, with or without antipolymerase II IgG from rabbits. Each oocyte nucleus was injected with $3.6 \mathrm{ng}$ DNA, 0.18 $\mu \mathrm{Ci}$ $\left[{ }^{3} \mathrm{H}\right] \mathrm{UTP}$ and, except for the controls, with $60 \mathrm{ng}$ IgG. After an incubation time of $6 \mathrm{~h}$, RNA 

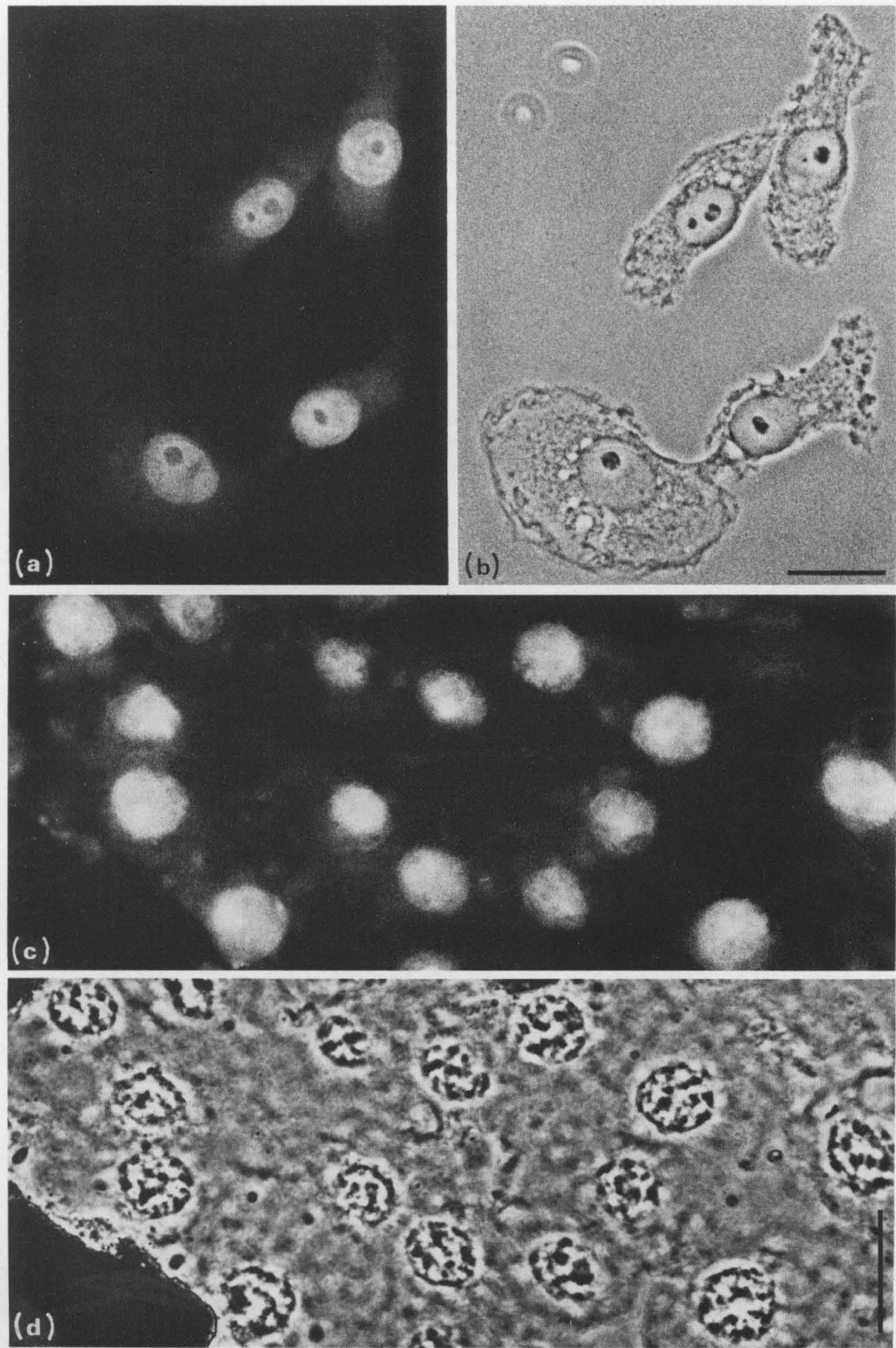

Fig. 1. 
was extracted (Mertz \& Gurdon, 1977) and analyzed by electrophoresis on $7 \mathrm{~m}-\mathrm{urea} / 10 \%$ polyacrylamide gels (Maniatis et al., 1975). Gels were processed for fluorography by the method of Chamberlain (1979).

Radioactivity incorporated into ribosomal RNA was assayed as follows. Nuclei of Xenopus oocytes were injected with $0 \cdot 12 \mu \mathrm{Ci}\left[{ }^{32} \mathrm{P}\right] \mathrm{CTP}$ together with $0 \cdot 24$ or $24 \mathrm{ng}$ IgG. RNA was extracted $3 \mathrm{~h}$ later and analyzed by electrophoresis on $1.2 \%$ agarose gels in "E-buffer" (Loening, 1969). Dried gels were exposed to Kodak X-Omat films at $-70^{\circ} \mathrm{C}$.

\section{Results}

When antibodies elicited from rabbits against Drosophila RNA polymerase II ("conventional antibodies") were examined by immunofluorescence microscopy on various amphibian cells they specifically stained the nuclei of cultured cells (e.g. $X$. laevis kidney cells, Fig. 1(a)) and of freeze-sectioned tissues (e.g. Pleurodeles liver, Fig. 1(c)). Nucleoli were not stained. The strong reaction observed indicates an extensive immunological similarity between the class II RNA polymerases of these phylogenetically distant species, in agreement with previous results indicating that eukaryotic RNA polymerases of type II are not only similar in terms of their antigenic properties but also in their biochemical properties and subunit polypeptides (e.g. Ingles, 1973; Kedinger et al., 1974; Hossenlopp et al., 1975; for further references see Chambon, 1975; Roeder, 1976). The absence of nucleolar fluorescence (Fig. 1(a)) illustrates the fact that the specific antibodies used did not bind to RNA polymerases I present in nucleoli of amphibian cells, in agreement with results obtained with salivary gland nuclei from $D$. melanogaster (Jamrich et al., 1978). Similar non-cross-reacting antibodies have been reported by Kedinger $e t$ al. (1974), Somers et al. (1975) and Lobban et al. (1976), whereas cross-reaction between RNA polymerases I and II has been reported for other antibody preparations (Hildebrandt et al., 1973; Ingles, 1973; Greenleaf et al., 1976; Buhler et al., 1976,1980; Guilfoyle, 1980). Essentially similar results were obtained with the monoclonal murine antibodies (Fig. 2).

When isolated lampbrush chromosomes from Pleurodeles oocytes were incubated with anti-polymerase II immunoglobulins at a concentration of $20 \mu \mathrm{g} / \mathrm{ml}$, according to the procedure outlined previously (Sommerville et al., 1978; Scheer et al., 1979a), only a faint fluorescence was noted along the lateral loops while the chromomeres were not decorated at all (results not shown here). The fluorescent staining observed, however, did not allow clear tracing of the delicate loop chromatin axis, and this might be because it is obscured by the comparatively huge masses of nascent ribonucleoprotein (RNP) fibril material that appeared to exhibit some unspecific binding of $\mathrm{IgG}$.

Injection of relatively high concentrations of rabbit and mouse non-immune IgG into nuclei of Pleurodeles oocytes did not affect the structural organization of the lampbrush chromosomes to any noticeable extent as judged by both light (Figs 3(a)

FIG. 1. Immunofluorescence microseopy ((a) and (e); epifluorescence optics) of cultured Xenopus kidney cells (a) and frozen sections of Pleurodeles liver (c) using conventionally produced rabbit antibodies to Drosophila RNA polymerase II (20 $\mathrm{gg}$ (a) and $0.1 \mathrm{mg}$ (b) $\mathrm{IgG} / \mathrm{ml})$. The nuclear interior, with the exception of the nucleoli, are intensely and specifically stained (a). (b) and (d) show the corresponding phase-contrast micrographs. Bars represent $20 \mu \mathrm{m}$. 

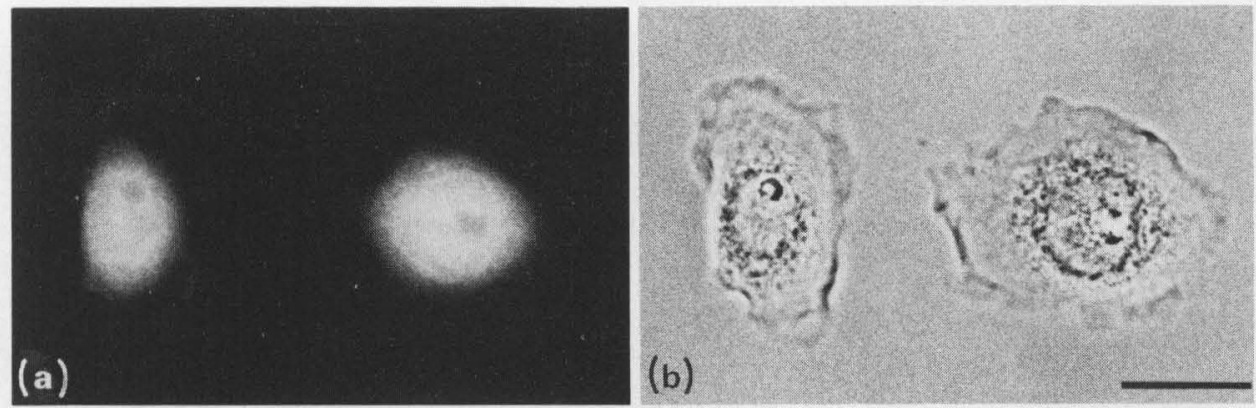

Fig. 2. Immunofluorescence microscopy of eultured $X$. laevis kidney cells after staining with monoclonal antibodies to RNA polymerase II $(0 \cdot 1 \mathrm{mg} \mathrm{IgG/ml})$ in epifluorescence (a) and phase-contrast (b) microseopy. The nuclei are stained throughout, with the exception of the nucleoli. Bar represents $20 \mu \mathrm{m}$.
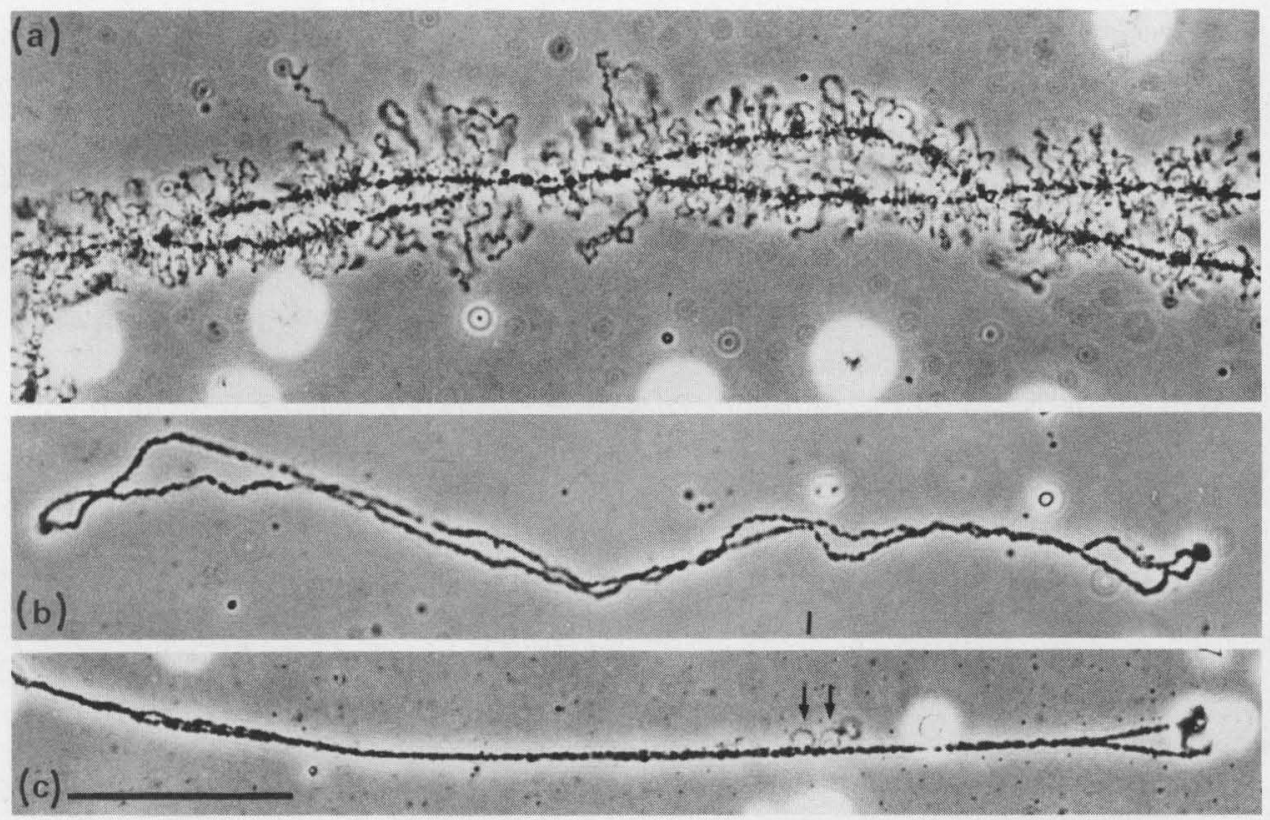

Fig. 3. Morphology of lampbrush chromosomes isolated from Pleurodeles oocytes $3 \mathrm{~h}$ after injection of non-immune rabbit IgG $(2 \cdot 6 \mathrm{mg} / \mathrm{ml} ;(\mathrm{a}))$ and after drug-induced inhibition of transcription ((b) and (c)). Injection of non-immune IgG (a) does not alter the structural appearance of the chromosomes as compared to control preparations, while incubation of oocytes in medium containing actinomycin D $(20 \mu \mathrm{g} / \mathrm{ml}$; (b)) or intracellular injection of $\alpha$-amanitin $(1 \mathrm{mg} / \mathrm{ml})$ causes loop retraction as seen in chromosome preparations made $1 \mathrm{~h}$ after application of the drugs. Occasionally, a few minor loops are recognized that seem to be refractory to inhibition by $\alpha$-amanitin (arrows in (c)). Bar represents $50 \mu \mathrm{m}$ ((a) to (c) are magnified to the same scale). 
and 9(a)) and electron (Scheer et al., 1979a) microscopy (for descriptions of the morphology of normal lampbrush chromosomes see Callan, 1963; Lacroix, 1968; Angelier \& Lacroix, 1975; Scheer et al., 1976,1979b). The same negative result was obtained after injection of various kinds of specific antibodies such as guinea-pig IgG against nucleoplasmin (Laskey \& Earnshaw, 1980; Krohne \& Franke, 1980a,b), rabbit IgG against heterogeneous nuclear RNP (hnRNP) from Triturus cristatus (cf. Scheer et al., 1979a), tubulin (Jockusch et al., 1979) and chicken IgG against core proteins of mouse hnRNP (Jones et al., 1980).

By contrast, inhibition of transcription by incubation of intact oocytes in medium containing actinomycin D or by injecting $\alpha$-amanitin into the cytoplasm or the nucleus caused dramatic changes in the morphology of the chromosomes (Fig. 3): the lateral loops retracted rapidly, collapsed and integrated into the chromomeres and, 60 minutes after drug administration, two slightly thickened axes, composed of longitudinally amalgamated chromomeres, remained of each bivalent, often in close lateral association for substantial parts of their lengths (Fig. 3(b) and (c); see also Izawa et al., 1963; Snow \& Callan, 1969; Mancino et al., 1971).

After injection of rabbit serum IgG (conventional antibodies) against RNA polymerase II into nuclei of Pleurodeles oocytes at relatively high concentrations ( $2 \mathrm{mg} / \mathrm{ml}$, i.e. 20 to $30 \mathrm{ng}$ IgG per nucleus), all lateral loops of the lampbrush chromosomes disappeared rapidly and were almost completely retracted into the chromosome axes within five minutes (Fig. 4(a)). When chromosomes were prepared several hours after injection, we consistently noted a considerable shortening of their overall lengths, concomitant with axial thickening (Fig. 4(b)). A similar rapid retraction of the lateral loops occurred after injection of a $1: 10$ dilution $(0.2 \mathrm{mg} / \mathrm{ml}$; Fig. $4(\mathrm{c}))$ of the antibody. A $1: 100$ dilution $(0.2$ to $0.3 \mathrm{ng}$ IgG per nucleus) also caused drastic shortening of most lateral loops within five minutes, but a number of small loops could still be recognized along the chromosome axes (Fig. 4(d)). After prolonged exposure, these residual small loops also disappeared gradually and were hardly visible in the light microscope 20 minutes after injection, except for a somewhat spiny contour of the surface of the chromosome axial body (Fig. 4(e)). Injection of antibodies into the cytoplasm did not affect the functional state of the lampbrush chromosomes, even at the highest concentrations used.

In electron microscopic spread preparations of nuclear contents made one hour after injection of non-diluted antibody solution (20 to $30 \mathrm{ng}$ per nucleus), three different structural components predominated: (1) transcriptionally inactive chromatin arranged in linear arrays of nucleosomal beads (Fig. 5(a)); (2) tandem arrays of active ribosomal RNA (rRNA) genes characterized by densely packed lateral RNP fibrils forming multiple length gradients separated by "spacer" regions (Fig. 5(b)), indistinguishable from those found in amplified nucleoli of normal oocytes (Miller \& Beatty, 1969; Franke et al., 1979); and (3) various forms of large aggregates of dense fibrils of RNP material.

That the transcriptional activity of the rRNA genes was not affected by injected antibodies to RNA polymerase II was also demonstrated by co-injection of $\left[{ }^{32} \mathrm{P}\right] \mathrm{CTP}$ into nuclei of Xenopus oocytes and subsequent analysis of rRNA, which was labeled to about the same extent as in control oocytes (Fig. 6(a)). In order to clarify whether the activity of the class III RNA polymerase was affected, we 

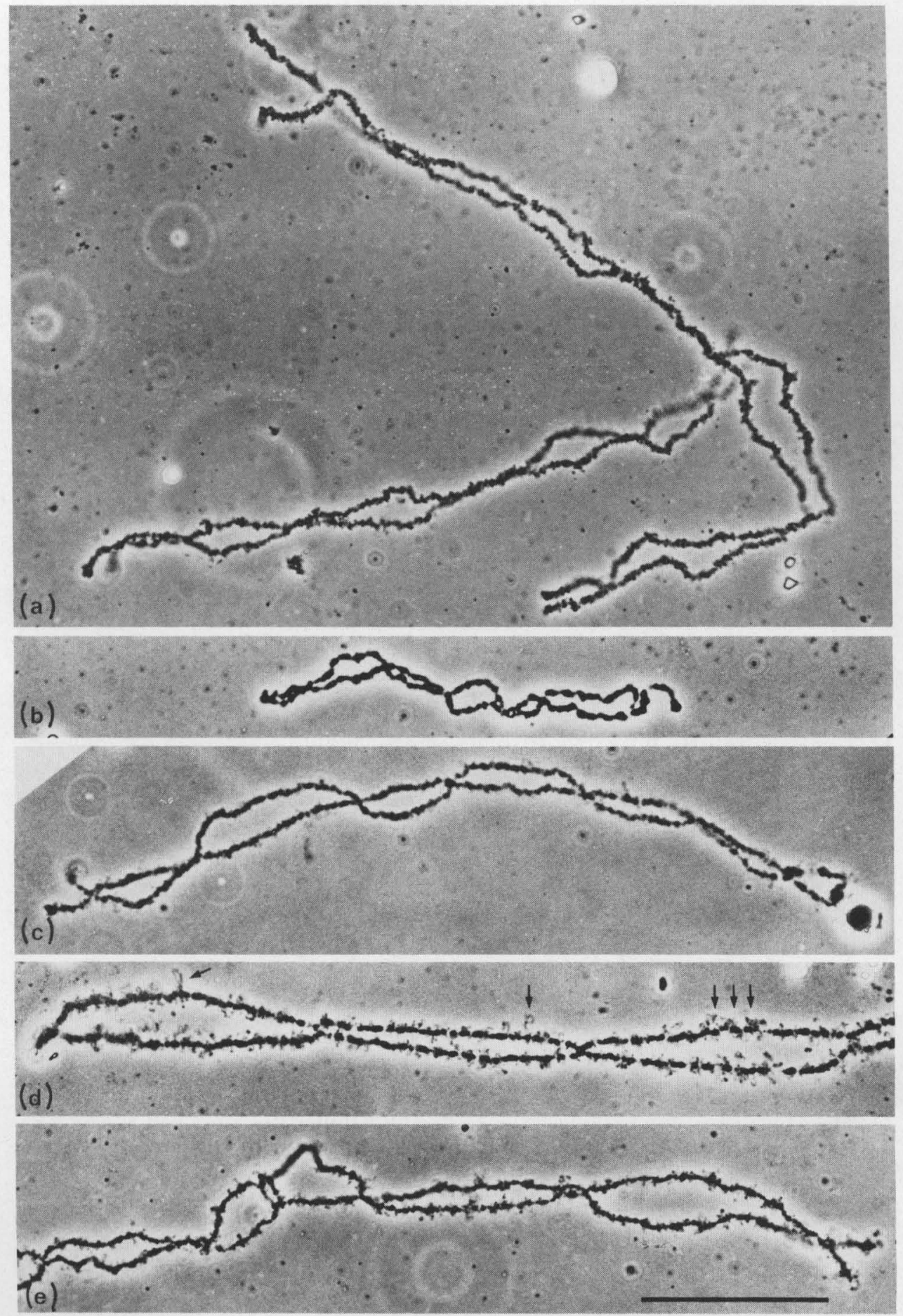

FIG. 4. 
injected cloned tRNA genes along with $\left[{ }^{3} \mathrm{H}\right] \mathrm{UTP}$ and high amounts of antibodies into the nuclei of Xenopus oocytes and analyzed the newly synthesized RNA by gel electrophoresis. As can be seen in Figure 6(b), the synthesis of tRNA by the injected genes, which is known to depend on the class III RNA polymerase (e.g. Melton \& Cortese, 1979; De Robertis \& Olson, 1979; Probst et al., 1979), was not affected by the injected antibodies. In oocytes of this stage, endogeneous tRNA synthesis was below the level of detectability, after injection of $\left[{ }^{3} \mathrm{H}\right] \mathrm{UTP}$ alone, when RNA from only two oocytes was applied per gel slot. These results demonstrate that the antibodies injected selectively inhibited, in the nucleus of the living cells, transcriptional processes catalyzed by RNA polymerase II, while the class I and III polymerases were not significantly affected. The frequently observed variability in rRNA synthesis between different batches of oocytes obtained from different animals does not influence the conclusion drawn. When rRNA was extracted from injected and non-injected oocytes of the same batch no significant difference in labeling was observed.

In order to analyze in greater detail the sequence of events leading to the collapse of the lateral loops of the lampbrush chromosomes, chromatin was prepared for electron microscopy at different times after injection of the conventional RNA polymerase II antibodies diluted $1: 100(20 \mu \mathrm{g} / \mathrm{ml})$. Figure 7 illustrates the situation 20 minutes after injection of this low concentration of antibody, corresponding to the light microscopic appearance of the chromosomes shown in Figure 4(e). While the amplified rRNA genes were fully active and indistinguishable from those of control oocytes, the overall density of lateral RNP fibrils along the axes of the chromosome loops was markedly reduced. The pattern of their arrangement was highly variable among different axial regions: regions retaining the close juxtaposition of lateral RNP fibrils were seen next to transcript-free regions ("gaps") or regions of reduced packing density of transcripts even within the same transcriptional unit (Fig. 7). Relatively long solitary lateral RNP fibrils were also frequently observed in such preparations as well as RNP fibrils not attached to chromatin. The chromatin axis between distantly spaced transcriptional complexes revealed a beaded appearance, similar to the morphological aspect seen during natural inactivation of transcription of chromosome loops (Scheer, 1978). These "beads" could be removed by spreading the chromatin in the presence of the detergent Sarkosyl, i.e. under conditions known to remove most proteins from the DNA except the transcribing RNA polymerase (Scheer, 1978); and thus, most likely reflected the organization of the chromatin into nucleosomal particles. RNP fibrils of various lengths not attached to chromatin axes were abundant in spread

FIG. 4. Loop retraction caused by injection of conventionally produced rabbit antibodies to RNA polymerase II into nuclei of living Pleurodeles oocytes. IgG solution at a concentration of $2 \mathrm{mg} / \mathrm{ml}$ induces very rapid retraction and collapse of the loops into the chromosome axes ((a), 5 min after injection: 2 bivalents are shown). Three hours after injection the chromosome axes appear thicker and are drastically shortened (b). Injection of $\mathrm{IgG}$ solution $1: 10$ diluted $(0 \cdot 2 \mathrm{mg} / \mathrm{ml})$ also results in rapid loop retraction ((c), $5 \mathrm{~min}$ after injection), whereas further dilution $(1: 100)$ apparently delays this process ((d), 5 min after injection). Numerous small loops (some are denoted by arrows in (d)) are still visible $5 \mathrm{~min}$ after antibody injection; however, after prolonged exposure $(20 \mathrm{~min}$ after injection, (e)) to this diluted $(1: 100)$ IgG solution most loops are almost eompletely retracted into the chromomeres. Bar represents $50 \mu \mathrm{m}$ ((a) to (e) are magnified to the same scale). 


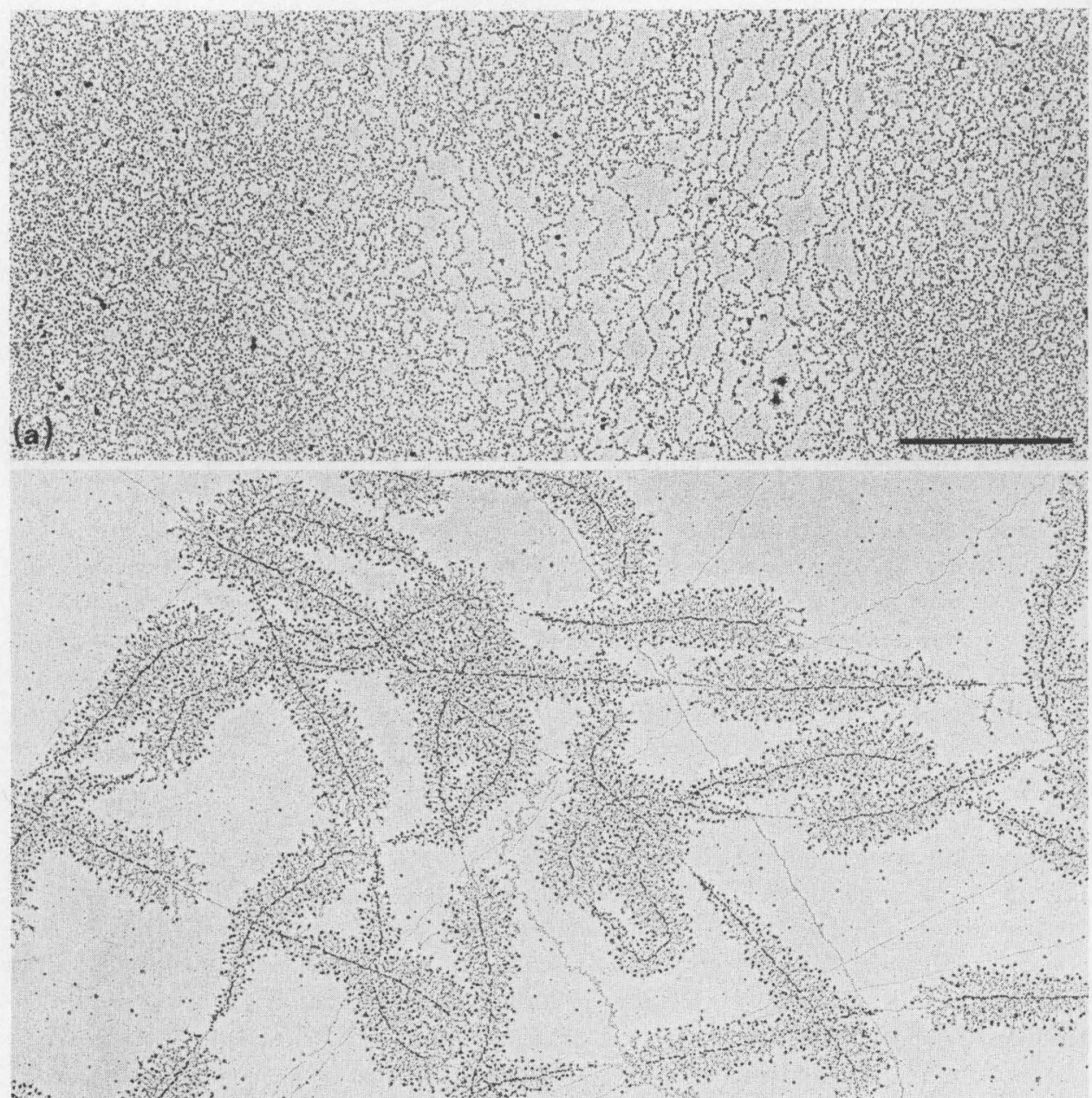
(a)

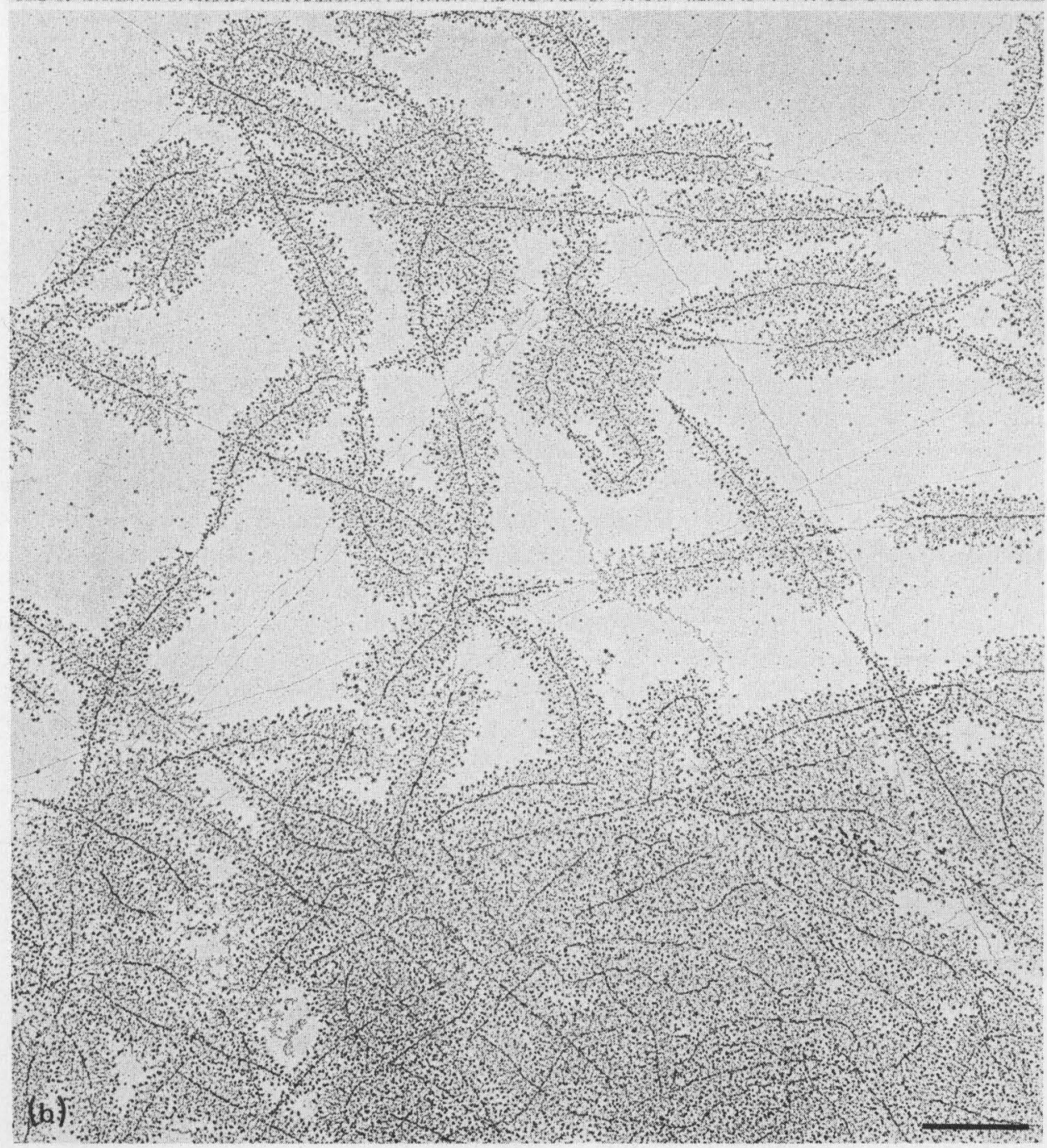

FIG. 5. 


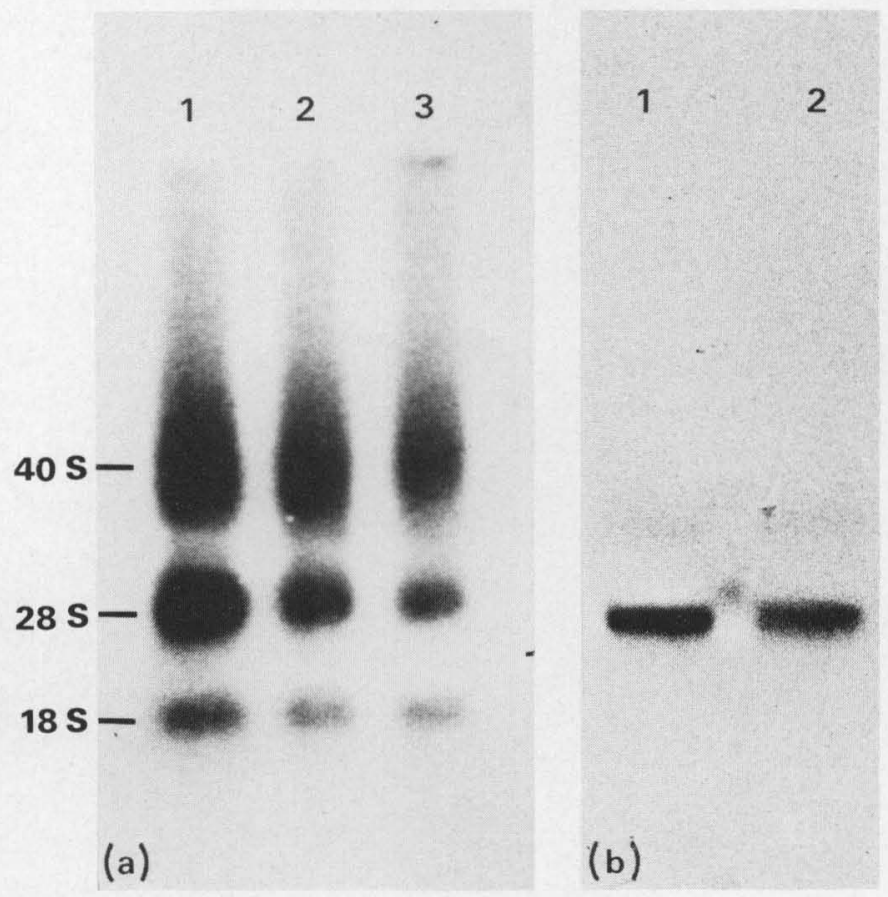

FiG. 6. Gel electrophoresis of RNA from $X$. laevis oocytes labeled in the presence of rabbit antibodies (IgG) to RNA polymerase II as seen by autoradiofluorography. (a) Ribosomal RNA species (40 S prerRNA, $28 \mathrm{~S}$ and $18 \mathrm{~S}$ rRNA) labeled after intranuclear injection of $\left[{ }^{32} \mathrm{P}\right] \mathrm{CTP}$ without antibodies (lane 1) and after co-injection of $24 \mathrm{ng}$ (lane 2) and $0 \cdot 24 \mathrm{ng}$ (lane 3) IgG per nucleus. RNA was extracted $3 \mathrm{~h}$ later and analyzed on a $1.2 \%$ agarose gel. Synthesis of rRNAs is not significantly inhibited by the antibodies injected (note the absence of correlation of intensity of radioactive labeling with the amount of antibodies injected). (b) tRNA labeled after injection of cloned tRNA genes and $\left[{ }^{3} \mathrm{H}\right] \mathrm{UTP}$, in the absence (lane 1) and presence of antibodies to RNA polymerase II ( $60 \mathrm{ng}$ IgG per nucleus; lane 2 ). The RNA was extracted from 20 oocytes $6 \mathrm{~h}$ after injection and analyzed on urea $10 \%$ polyacrylamide gels. RNA corresponding to 2 oocytes was applied to each slot of the gel.

preparations of nuclear contents after injection of RNA polymerase II antibody solution of various degrees of dilution (Fig. 8(c)). These free fibrils exhibited morphological features characteristic of nascent transcripts, such as typical ring- or bush-like formations or periodically arranged thickenings, and appeared to represent prematurely released transcripts.

Injection of monoclonal murine antibodies directed against the large subunits of Drosophila RNA polymerase II (Krämer et al., 1980) into nuclei of living amphibian oocytes also caused retraction of the chromosome loops (Fig. 9). The observed time course of inactivation, however, was different from the rapid loop retraction characteristically seen after injection of the conventionally produced rabbit

FIG. 5. Electron microseopic appearance of non-nucleolar chromatin (a) and of amplified nucleolar chromatin (b) $1 \mathrm{~h}$ after injection of rabbit antibodies to RNA polymerase II ( $2 \mathrm{mg} \mathrm{IgG} / \mathrm{ml})$. While the chromosomal chromatin shows the characteristic beaded (nucleosomal) configuration of transcriptionally inactive chromatin (a), the rRNA genes are apparently not affected at all by the antibodies injected (b). Bars represent $1 \mu \mathrm{m}$. 


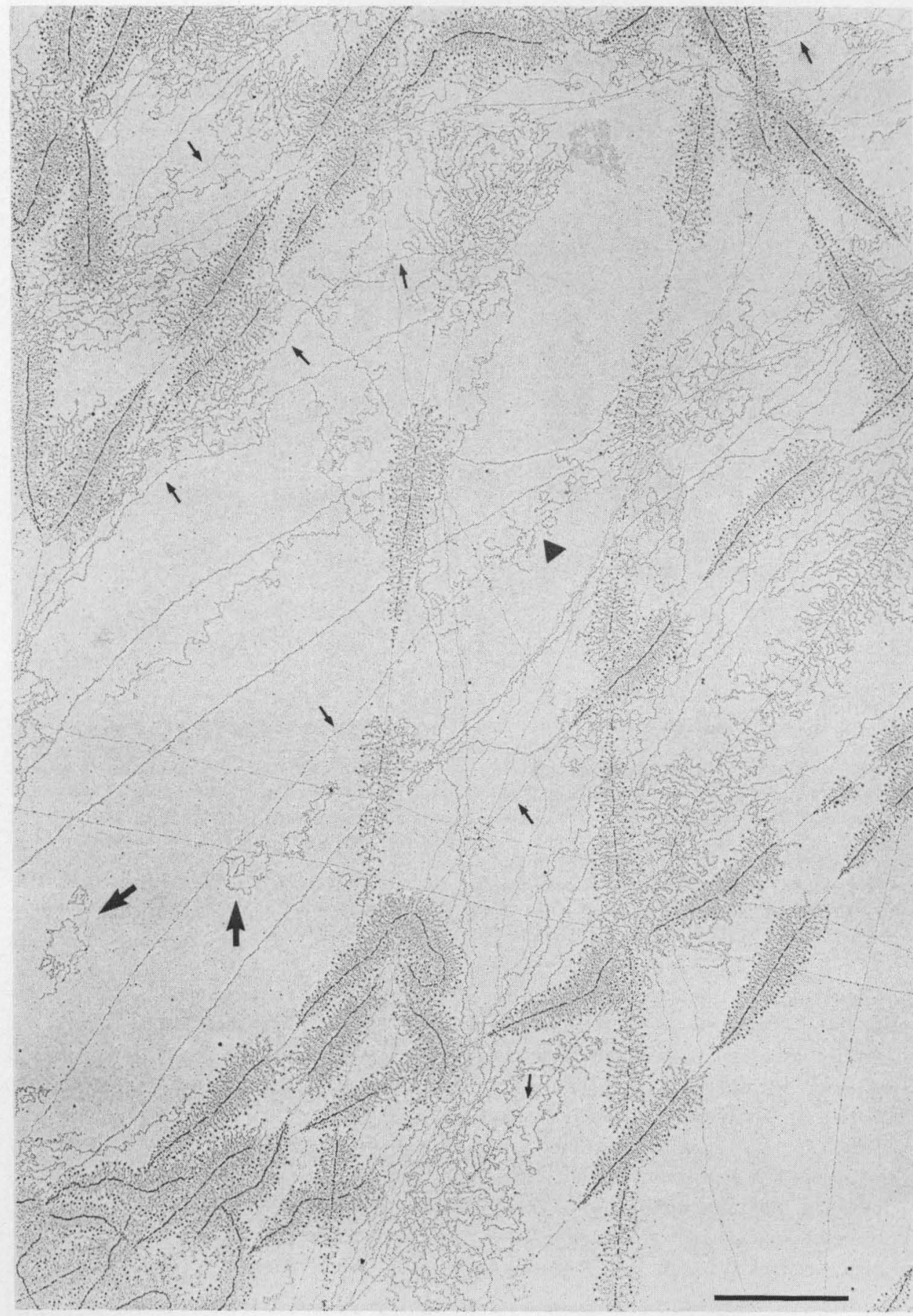

Fig. 7. Survey micrograph showing the electron microscopic appearance of transcriptional arrays of lampbrush chromosome loops and rRNA genes from Pleurodeles oocytes at intermediate stage of inhibition, i.e. $20 \mathrm{~min}$ after injection of highly diluted rabbit antibodies to RNA polymerase II (1:100, i.e. $20 \mu \mathrm{g} \mathrm{IgG} / \mathrm{ml}$ ). Several transcript-denuded chromatin axes are seen. A number of transcriptional units of chromosome loops are interrupted by transeript-free regions (some are denoted by small arrows) and/or show diluted coverage by transcript fibrils (e.g. at the triangle). Fibrillar structures resembling free RNP fibrils are also commonly seen (thick arrows). Nucleolar (rRNA) genes appear normal and are fully active. Bar indicates $2 \mu \mathrm{m}$. 
antibodies. Figure 9 illustrates the progressive reduction in loop size with increasing time after injection. After 4 hours the majority of the loops were completely retracted into the chromomeres, except for a few, still prominent, loop projections (Fig. 9(d)). Upon further exposure to the injected antibodies, these loops also became gradually smaller in size but some individual small loops could still be recognized as late as seven hours after injection (Fig. 9(f)). The progressive reduction of loop sizes and the selective retention of a few specific loops several hours after application of the antibodies can be explained by assuming that the monoclonal antibodies selectively inhibited the initiation but not the elongation of the RNA polymerase II. Such a mechanism would cause a gradual stripping of the matrix material from all chromosome loops at a roughly constant rate and would also explain the observed delayed retraction of some specific loops on account of the presence of a heterogeneous mixture of loop sizes in the normal chromosomes. The fact that the monoclonal antibody does not inhibit RNA polymerase II activity in vitro, using denatured DNA as template (Krämer \& Bautz, 1981), agrees with such an interpretation.

\section{Discussion}

The results of the present study demonstrate that antibodies to RNA polymerase II inhibit, with great specificity, the transcription in the lateral loops of lampbrush chromosomes when they are injected into the nucleus of a living cell, the amphibian oocyte. This finding corroborates and extends results obtained by various other authors using in vitro assays (Ingles, 1973; Hildebrandt et al., 1973; Kedinger et al., 1974 ; Somers et al., 1975; Hossenlopp et al., 1975; Lobban et al., 1976; Buhler et al., 1976; Greenleaf et al., 1976) and represents the first demonstration of an interference with transcription in the living cell, by an antibody directed against a defined enzyme. For future studies, we expect that such injection experiments, using antibodies directed against defined polymerase subunits, transcription factors and proteins modulating transcription (e.g. see Crippa, 1970; Shiokawa et $a l ., 1977$; Crampton \& Woodland, 1979a,b; Sekimizu et al., 1979a,b; Ueno et al., 1979; Matsui et al., 1980; Segall et al., 1980; Honda \& Roeder, 1980; Pelham \& Brown, 1980), will eventually lead to a better understanding of the functional role of individual polymerase subunits and of the mechanisms involved in regulation of transcriptional events in the living cells. A further advantage of the in vivo system described here is demonstrated by the findings that transcription is not only inhibited by antibodies to components known to be involved in transcription, such as the RNA polymerase complex, but also by antibodies to other chromatin components, such as histones (Scheer et al., 1979a) and high mobility group (HMG)proteins (Scheer et al., unpublished results). In contrast, antibodies directed against the hnRNP product, including nascent RNP fibrils (Sommerville et al., 1978; Martin et al., 1970), apparently do not interfere with transcription. Therefore, the nuclear injection technique should provide a valuable means to probe for the presence of specific components in transcriptionally active regions of chromatin or their involvement in transeription and other nuclear processes. Microinjection of 

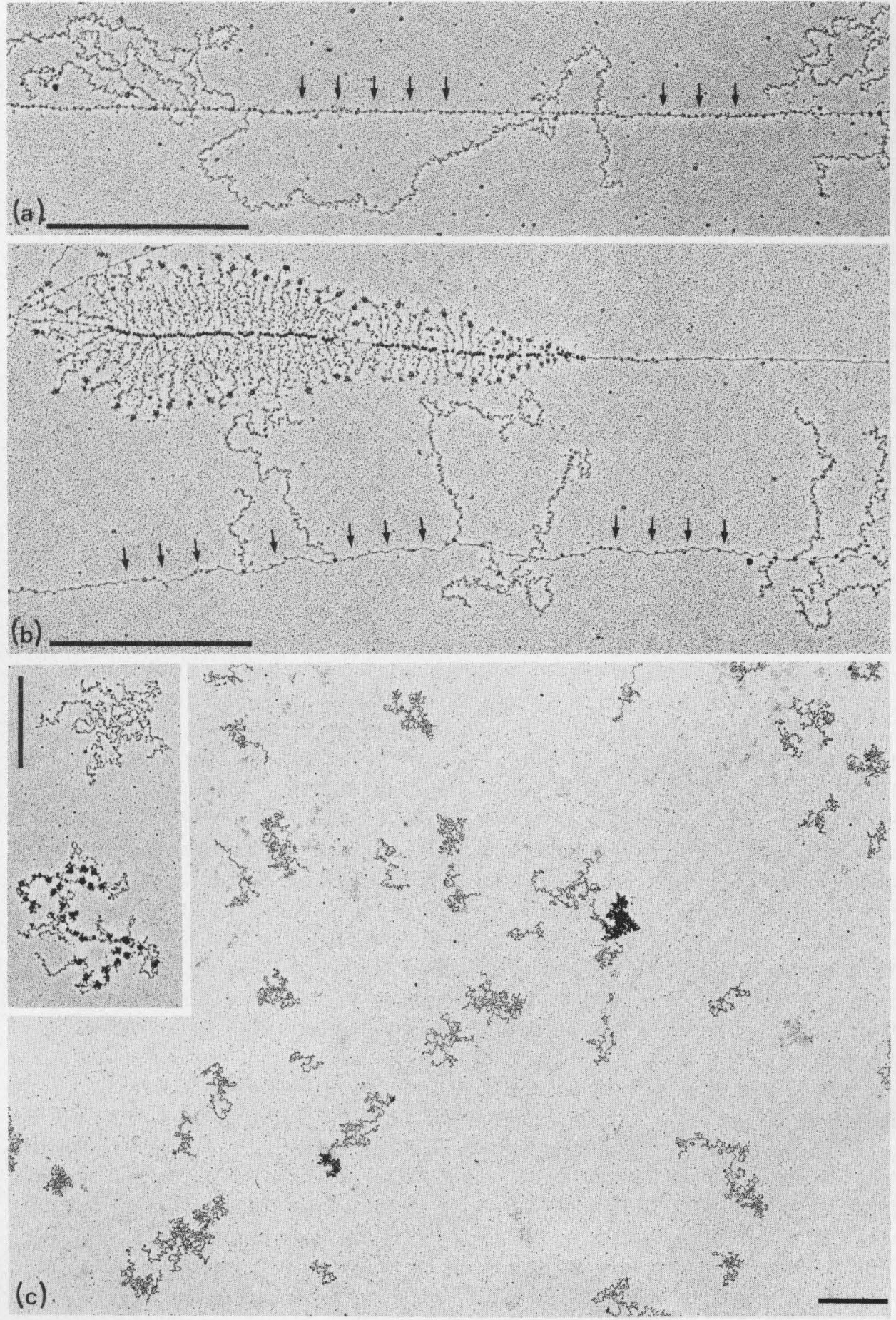

FIG. 8 . 
antibodies specific to one of the three different RNA polymerases into living cells, combined with morphological examination at the light and electron microscopic level, should also help in deciding whether a given transcriptional structure is the result of the action of either polymerase I, II or III.

The rapid loop retraction observed after injection of conventionally produced antibodies against RNA polymerase II provides clear evidence that they act directly on the initiated RNA polymerase molecules. The binding of the antibodies to the highly stable ternary transcription complexes (e.g. Krakow et al., 1976) leads to the rapid premature release of the nascent RNP transcripts from the chromosomal loop axes, followed by loop retraction. At the moment we do not know whether binding of the antibodies to the polymerase molecules interferes primarily with one of the steps of the elongation reaction or directly with the binding of the enzyme to the chromatin template. From electron microscopic preparations, however, it is clear that the RNA polymerase particles are actually detached from the chromatin. Whether the prematurely released RNP fibrils remain associated with the RNA polymerases or whether the transcriptional complexes dissociate simultaneously into their various components remains to be clarified.

The structural instability of the transcriptional complexes in the living oocyte seems to be a direct consequence of inhibition of transcription in general. Premature release of transcripts and subsequent loop retraction is observed after blocking transcription by a variety of agents such as injected antibodies to histone H2B (Scheer et al., 1979a), HMG-1 (Scheer et al., unpublished results), RNA polymerases II (this study), actinomycin D (Izawa et al., 1963; Snow \& Callan, 1969) and $\alpha$-amanitin (Mancino et al., 1971). Thus, the maintenance of stable transcriptional complexes in the living cell seems to require continuing transcription. By contrast, the behavior of transcriptional complexes in vitro is strikingly different. For example, in pure in vitro systems as well as in isolated oocyte nuclei transcriptional complexes do not dissociate upon addition of $\alpha$ amanitin in concentrations that completely inhibit transcription (Mancino et al., 1971 ; Cochet-Meilhac \& Chambon, 1974; Schultz et al., 1981), and the structural organization of lampbrush chromosomes is largely preserved. It would be interesting to identify the mechanism responsible in the living cell for the dissociation of transcriptional complexes upon cessation of transcription, and to clarify whether it is related to normal release of terminated transcriptional products.

From our demonstration that the injected antibodies to RNA polymerase II do not interfere, to any significant extent, with activities of class I and III RNA

FIG. 8. Same preparation as described in the legend to Fig. 7. The beaded configuration of the loop chromatin axis between distantly spaced transcripts (arrows in (a)) is no longer visible after spreading in the presence of $0.3 \%$ Sarkosyl NL-30 (arrows in (b)). Note the difference in density of transcriptional complexes between rDNA-chromatin and chromosomal-loop chromatin. In such preparations numerous free RNP fibrils of different lengths are observed on the electron microscopic grids (c), which reveal ultrastructural features characteristic for nascent transcripts such as ring-like formations and higherorder packing into regular knob-like particles ( 2 of the more frequent morphological forms are shown in the inset to (c)). Bars indicate $1 \mu \mathrm{m}$ ((a), (b) and inset to (c)) and $2 \mu \mathrm{m}$ (c). 

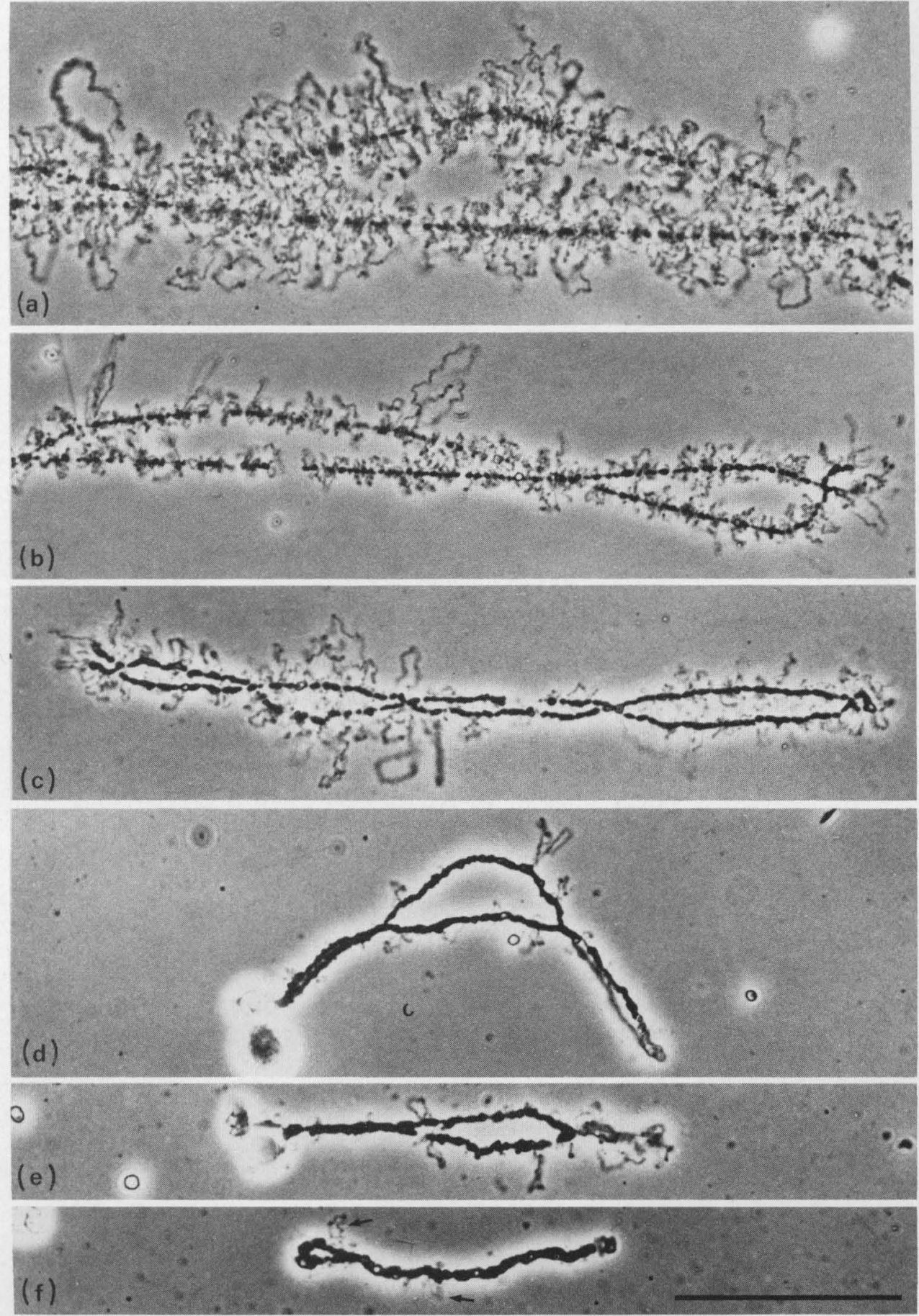

FIG. 9. 
polymerases, yet cause complete retraction of all chromosomal loops, it is clear that the transcriptional units containing tRNA and $5 \mathrm{~S}$ rRNA genes are not located in lateral loops visible in the light microscope. Our failure to detect loops resistant to the action of antibodies to polymerase II suggests that these highly reiterated genes are transcribed in or near the chromosome axis or chromomeres in agreement with recent observations in lampbrush chromosomes of Notophthalmus viridescens (Schultz et al., 1981).

In addition to the high number of RNA polymerases initiated and engaged in transcription, nuclei of amphibian oocytes also contain a large pool of RNA polymerases dispersed in the nuclear sap (Roeder, 1974; Hollinger \& Smith, 1976). The absolute amount of soluble RNA polymerases has not been determined in oocyte nuclei of Pleurodeles and Xenopus. At any rate, our data demonstrate that the antibodies injected are not completely bound and "trapped" by free RNA polymerases but react with initiated RNA polymerase molecules.

We thank Drs B. M. Jockusch, T. Martin, M. Bustin and H. Küpper for gifts of antibodies and Professor W. W. Franke for stimulating discussions and for reading and correcting the manuscript. Mr K. Mähler is acknowledged for his excellent photographic assistance. This work was supported by grants from the Deutsche Forschungsgemeinschaft and the Stiftung Volkswagenwerk.

\section{REFERENCES}

Angelier, N. \& Lacroix, J. C. (1975). Chromosoma (Berlin), 51, 323-335.

Brown, D. D. \& Gurdon, J. (1977). Proc. Nat. Acad. Sci., U.S.A. 74, 2064-2068.

Buhler, J.-M., Iborra, F., Sentenac, A. \& Fromageot, P. (1976). J. Biol. Chem. 251, 17121717.

Buhler, J.-M., Huet, J., Davies, K. E., Sentenac, A. \& Fromageot, P. (1980). J. Biol. Chem. 255, 9949-9954.

Bustin, M., Simpson, R. T., Sperling, R. \& Goldblatt, R. (1977). Biochemistry, 16, 5381-5385.

Callan, H. G. (1963). Int. Rev. Cytol. 15, 1-34.

Chamberlain, J. P. (1979). Anal. Biochem. 98, 132-135.

Chambon, P. (1975). Annu. Rev. Biochem. 44, 613-638.

Cochet-Meilhac, M. \& Chambon, P. (1974). Biochim. Biophys. Acta, 353, 160-184.

Crampton, J. M. \& Woodland, H. R. (1979a). Develop. Biol. 70, 453-466.

Crampton, J. M. \& Woodland, H. R. (1979b). Develop. Biol. 70, 467-478.

Crippa, M. (1970). Nature (London), 227, 1138-1140.

De Robertis, E. M. \& Olson, M. V. (1979). Nature (London), 278, 137-143.

FIG. 9. Progressive retraction of the lateral loops of Pleurodeles lampbrush chromosomes after injection of monoclonal murine IgG against the large subunits of RNA polymerase II into oocyte nuclei of Pleurodeles ((b) to (f)). Part of bivalent isolated from a control-injected oocyte $(2 \mathrm{mg} / \mathrm{ml} \mathrm{non}$-immune mouse IgG, $7 \mathrm{~h}$ after injection) is shown in (a). Upon injection of RNA polymerase antibodies the loops become gradually shorter as seen in preparations made $1 \mathrm{~h}$ (b) and $2 \mathrm{~h}$ (c) after injection. Four hours after injection of RNA polymerase antibodies most loops are completely retracted (d). The remaining small loops, which may reflect the residues of some giant loops in the normal state (a), then further retract gradually during an extended period of time ((e) $5 \mathrm{~h}$; (f) $7 \mathrm{~h}$ ); however, a few small residual loops are still recognized even after $7 \mathrm{~h}$ (arrows in (f)). Note progressive "contraction" (foreshortening and thickening) of the chromosome axes ((b) to (f)). Bar indicates $50 \mu \mathrm{m}$ ((a) to (f) are magnified to the same scale). 
Franke, W. W., Scheer, U., Spring, H., Trendelenburg, M. F. \& Zentgraf, H. (1979). In The Cell Nucleus (Busch, H., ed.), vol. 7, pp. 49-95, Academic Press, New York.

Greenleaf, A. L. \& Bautz, E. K. F. (1975). Eur. J. Biochem. 60, 169-179.

Greenleaf, A. L., Krämer, A. \& Bautz, E. K. F. (1976). In RNA Polymerase (Losick, R. \& Chamberlin, M., eds), pp. 793-801, Cold Spring Harbor Laboratory, New York.

Guilfoyle, T. J. (1980). Biochemistry, 19, 5966-5972.

Gurdon, J. B. (1976). J. Embryol. Expt. Morphol. 36, 523-540.

Hildebrandt, A., Sebastian, J. \& Halvorson, H. O. (1973). Nature New Biol. 246, 73-74.

Hollinger, T. G. \& Smith, L. D. (1976). Develop. Biol. 51, 86-97.

Honda, B. M. \& Roeder, R. G. (1980). Cell, 22, 119-126.

Hossenlopp, P., Wells, D. \& Chambon, P. (1975). Eur. J. Biochem. 58, 237-251.

Hovemann, B., Sharp, S., Yamada, H. \& Söll, D. (1980). Cell, 19, 889-895.

Ingles, C. J. (1973). Biochem. Biophys. Res. Commun. 55, 364-371.

Izawa, M., Allfrey, V. G. \& Mirsky, A. E. (1963). Proc. Nat. Acad. Sci., U.S.A. 49, 544-551.

Jamrich, M., Greenleaf, A. L. \& Bautz, E. K. F. (1977). Proc. Nat. Acad. Sci., U.S.A. 74, 2079-2083.

Jamrich, M., Greenleaf, A. L., Bautz, F. A. \& Bautz, E. K. F. (1978). Cold Spring Harbor Symp. Quant. Biol. 42, 389-396.

Jockusch, H., Jockusch, B. M. \& Burger, M. M. (1979). J. Cell Biol. 80, 629-641.

Jones, E. E., Okamura, C. S. \& Martin, T. E. (1980). J. Cell Biol. 86, 235-243.

Kedinger, C., Gissinger, F. \& Chambon, P. (1974). Eur. J. Biochem. 44, 421-436.

Krakow, J. S., Rhodes, G. \& Jovin, T. M. (1976). In RNA Polymerase (Lossick, R. \& Chamberlin, M., eds), pp. 127-157, Cold Spring Harbor Laboratory, New York.

Krämer, A. \& Bautz, E. K. F. (1981). Eur. J. Biochem., in the press.

Krämer, A., Haars, R., Kabisch, R., Will, H., Bautz, F. A. \& Bautz, E. K. F. (1980). Mol. Gen Genet. 180, 193-199.

Kressmann, A., Clarkson, S. G., Pirotty, V. \& Birnstiel, M. L. (1978). Proc. Nat. Acad. Sci., U.S.A. 75, 1176-1180.

Krohne, G. \& Franke, W. W. (1980a). Proc. Nat. Acad. Sci., U.S.A. 77, 1034-1038.

Krohne, G. \& Franke, W. W. (1980b). Expt. Cell Res. 129, 167-189.

Lacroix, J. C. (1968). Ann. Embryol. Morphogenèse 1, 179-202.

Laskey, R. A. \& Earnshaw, W. C. (1980). Nature (London), 286, 763-767.

Lobban, P. E., Siminovitch, L. \& Ingles, C. J. (1976). Cell, 8, 65-70.

Loening, U. E. (1969). Biochem. J. 113, 131-138.

Mancino, G., Nardi, I., Corvaja, N., Fiume, L. \& Marinozzi, V. (1971). Expt. Cell Res. 64, 237-239.

Maniatis, T., Jeffrey, A. \& van de Sande, H. (1975). Biochemistry, 14, 3787-3794.

Martin, T., Pullman, J. M. \& MeMullen, M. D. (1980). In Cell Biology (Prescott, D. M. \& Goldstein, L., eds), vol. 4, pp. 137-174, Academic Press, New York.

Matsui, T., Segall, J., Weil, P. A. \& Roeder, R. G. (1980). J. Biol. Chem. 255, 11992-11996.

Melton, D. A. \& Cortese, R. (1979). Cell, 18, 1165-1172.

Mertz, J. E. \& Gurdon, J. B. (1977). Proc. Nat. Acad. Sci., U.S.A. 74, 1502-1506.

Miller, O. L. \& Beatty, B. R. (1969). Science, 164, 955-957.

Pelham, H. R. B. \& Brown, D. D. (1980). Proc. Nat. Acad. Sci., U.S.A. 77, 4170-4174.

Plagens, U., Greenleaf, A. L. \& Bautz, E. K. F. (1976). Chromosoma (Berlin), 59, 157-165.

Probst, E., Kressmann, A. \& Birnstiel, M. L. (1979). J. Mol. Biol. 135, 709-732.

Rafferty, K. A. (1969). In Biology of Amphibian Tumors (Mizell, M., ed.), pp. 52-81, Springer-Verlag, Berlin.

Roeder, R. G. (1974). J. Biol. Chem. 249, 249-256.

Roeder, R. G. (1976). In RNA Polymerase (Losick, R. \& Chamberlin, M., eds), pp. 285-329, Cold Spring Harbor Laboratory, New York.

Scheer, U. (1978). Cell, 13, 535-549.

Scheer, U., Franke, W. W., Trendelenburg, M. F. \& Spring, H. (1976). J. Cell Sci. 22, 503519.

Scheer, U., Sommerville, J. \& Bustin, M. (1979a). J. Cell Sci. 40, 1-20. 
Scheer, U., Spring, H. \& Trendelenburg, M. F. (1979b). In The Cell Nucleus (Busch, H., ed.), vol. 7, pp. 3-47, Academic Press, New York.

Schultz, L. D., Kay, B. K. \& Gall, J. G. (1981). Chromosoma, (Berlin), in the press.

Segall, J., Matsui, T. \& Roeder, R. G. (1980). J. Biol. Chem. 255, 11986-11991.

Sekimizu, K., Mizuno, D. \& Natori, S. (1979a). Expt. Cell Res. 124, 63-72.

Sekimizu, K., Nakanishi, Y., Mizuno, D. \& Natori, S. (1979b). Biochemistry, 18, 1582-1588.

Shiokawa, K., Kawahara, A., Misumi, Y., Yasuda, Y. \& Yamana, K. (1977). Develop. Biol. 57, 210-214.

Snow, M. H. L. \& Callan, H. G. (1969). J. Cell Sci. 5, 1-25.

Somers, D. G., Pearson, M. L. \& Ingles, C. J. (1975). J. Biol. Chem. 250, 4825-4831.

Sommerville, J. (1977). Int. Rev. Biochem. 15, 79-156.

Sommerville, J., Crichton, C. \& Malcolm, D. (1978). Chromosoma (Berlin), 66, 99-114.

Ueno, K., Sekimizu, K., Mizuno, D. \& Natori, S. (1979). Nature (London), 277, 145-146.

Edited by P. Chambon 